\title{
Glycaemic control does not appear to correlate with mortality from COVID-19
}

\author{
EUNICE O WIAFE, JAGANNATH GOPALAPPA, VIJAY JAYAGOPAL \\ Centre for Diabetes and Endocrinology, York Teaching Hospitals NHS Foundation Trust, York, UK
}

\begin{abstract}
We welcome correspondence and research letters to the journal.

Research letters should be no more than 800 words with a maximum of 10 references, one table and/or one figure. These will usually be short reports of interim work or final reports of research that do not warrant a full $\mathrm{HbA}_{1 \mathrm{c}}$, glycaemic control

\section{Background}

Severe acute respiratory syndrome coronavirus 2 (SARS-CoV-2) infection, otherwise known as COVID-19, was declared to be a pandemic by WHO in March 2020 with the virus claiming over 1.9 million lives worldwide. The UK has been the worst hit country in Europe, with the virus claiming close to 82,000 lives to date. Many of these patients have been identified to be elderly men with underlying comorbidities, and diabetes mellitus has been found to be a major comorbid disease associated with up to $34.6 \%$ of COVID-19-related deaths in some cohorts: $31.1 \%$ in Italy, 33.5\% here in the UK and $34.6 \%$ in China. ${ }^{1-4}$
\end{abstract} research paper publication. Letters to the editor relating to any articles published in the Journal Letters should ideally be submitted within 2 months following publication of the article on which the authors wish to comment, and should be no more than 600 words with up to 5 references
Key words: COVID-19, diabetes, deaths,

\section{Aims}

It is unclear if the diabetes-related COVID-19 deaths at our hospital were in people with demographics that were consistent with what is being reported elsewhere. This analysis was therefore undertaken to identify the characteristics of patients with diabetes who died from COVID-19 at our hospital during the peak of the pandemic.

\section{Method}

This was a retrospective analysis into the COVID19 deaths recorded in the York Teaching Hospitals NHS Foundation Trust between March and June 2020. We collected data on age, gender, type of diabetes, duration of diabetes, last recorded glycated haemoglobin $\left(\mathrm{HbA}_{1 \mathrm{c}}\right)$, body mass index (BMI) and associated comorbidities in diabetes patients who died from COVID-19.

\section{Results}

The results are shown in Table 1 and Figure 1. There were 214 deaths from COVID-19 reported in our hospital over the period. Of these, 65 patients $(30.1 \%)$ had diabetes; $97 \%$ of this cohort had type 2 diabetes, with only one patient having type 1 diabetes and one patient had drug-induced diabetes. $66 \%$ were male, $83.1 \%$ were aged $>70$ years and $72.3 \%$ had had diabetes for $>5$ years.

Of those with diabetes, $57 \%$ had well managed diabetes based on NICE guidance $\left(\mathrm{HbA}_{1 \mathrm{c}}\right.$ $<58 \mathrm{mmol} / \mathrm{mol}$ ); $70.8 \%$ had an $\mathrm{HbA}_{1 \mathrm{c}}$ that would allow elective surgery if needed $\left(\mathrm{HbA}_{1 \mathrm{c}}<69\right.$ $\mathrm{mmol} / \mathrm{mol}$ ) and $86.1 \%$ had $\mathrm{HbA}_{1 \mathrm{c}}<86 \mathrm{mmol} /$ mol. $63 \%$ of the patients were overweight or obese and $97 \%$ had at least one other comorbidity in addition to diabetes and obesity. The comorbidities were primarily hypertension, ischaemic heart disease, heart failure and cerebrovascular disease.

\section{Discussion}

Glycaemic control

Previous reports have reported an increased risk of infections in people with diabetes, especially respiratory tract infections like the severe acute respiratory syndrome (SARS), Middle East respiratory syndrome (MERS) and H1N1 influenza outbreaks, and this risk was increased with worsening glycaemic control. ${ }^{5-7}$

However, in the case of COVID-19, evidence from China and Italy suggests that diabetes does not increase the risk of contracting COVID-19. The prevalence of diabetes in people infected with COVID-19 was similar to or lower than the prevalence of diabetes in the general population of similar age groups. Instead, they found a higher prevalence of diabetes among patients with severe COVID-19 and, moreover, poor glycaemic control was associated with a higher risk of death. ${ }^{2-4,8,9}$

In our cohort, people with diabetes who died from COVID-19 had $\mathrm{HbA}_{1 \mathrm{c}}$ measurements that would not be considered to be unduly elevated. In this group, more than half had $\mathrm{HbA}_{1 \mathrm{c}}$ of 58 $\mathrm{mmol} / \mathrm{mol}$ or lower.

Age and gender

Older age of $\geq 70$ years is known to be an independent predictor of in-hospital mortality. ${ }^{7}$ Our 
Table 1 Demographics, diabetes history and body mass index (BMI)

$\left.\begin{array}{lll}\hline \text { Demographics } & \text { Male } & \begin{array}{l}\text { No (\%) of } \\ \text { patients }\end{array} \\ \text { Gender } & \text { Female } & 43(66.2 \%) \\ \text { Age (years) } & <60 & 22(33.8 \%)\end{array}\right)$

Figure 1. Glycaemic control $\left(\mathrm{HbA}_{1 \mathrm{c}}, \mathrm{mmol} / \mathrm{mol}\right)$

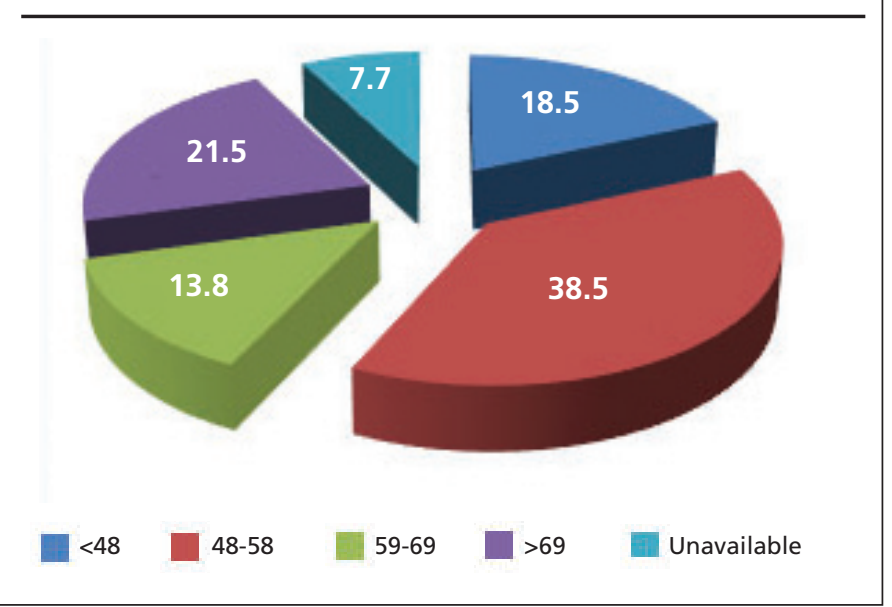

data found a similarly strong correlation between age and risk of death, with $83.1 \%$ of those diabetes patients who died being aged $\geq 70$ years and almost all ( $98.5 \%$ ) being $\geq 60$ years. More severe disease was found in older males in almost all regions of the world, and our data were consistent with this with about twice as many deaths with COVID-19 and diabetes in males. ${ }^{4}$

\section{Type of diabetes/duration of diabetes}

Morbidity in COVID-19 has been found to be associated with predominantly type 2 diabetes. In addition, Baron et al reported that both type 1 and type 2 diabetes were independently associated with an increased risk of in-hospital mortality from COVID-19. ${ }^{2-4}$ In our cohort, $97 \%$ of the patients had type 2 diabetes and only one patient (1.5\%) had type 1 diabetes. Over $72 \%$ had diabetes for 5 years or longer.

\section{Obesity/other comorbidities}

Our cohort was consistent with others, with $63 \%$ of those who died being overweight or obese and $97 \%$ had at least one comorbidity other than diabetes and obesity.

\section{Conclusion}

Consistent with previous reports, in our hospital people with diabetes who died from COVID-19 were more likely to be older males with a longer duration of diabetes and higher prevalence of obesity and other comorbidities. However, in contrast to previous reports, glycaemic control as measured by $\mathrm{HbA}_{1 \mathrm{c}}$ did not appear to correlate with mortality. We do acknowledge the possibility that this may be due to the small cohort size.

\section{Conflict of interest None. Funding None}

\section{References}

1. GOV.UK. Deaths within 28 days of positive test. https://coronavirus.data.gov.uk/deaths (accessed 20 August 2020).

2. Apicella M, Campopiano MC, Mantuano M, Mazoni L, Coppelli A, Del Prato S. COVID-19 in people with diabetes: understanding the reasons for worse outcomes. Lancet Diabetes Endocrinol 2020;8(9):782-92. https://doi.org/10.1016/S2213-8587(20)30238-2

3. Holman N, Knighton P, Kar P, et al. Risk factors for COVID-19-related mortality in people with type 1 and type 2 diabetes in England: a population-based cohort study. Lancet Diabetes Endocrinol 2020;8(10):82333. https://doi.org/10.1016/ \$2213-8587(20)30271-0

4. Baron E, Bakhai C, Parthar K, et al. Association of type 1 and type 2 diabetes with COVID-19 related mortality in England: a whole population study. Lancet Diabetes Endocrinol 2020;8(10):813-22. https://doi.org/ 10.1016/S2213-8587(20)30272-2

5. Booth CM, Latukas LM, Tomlinson GA, et al. Clinical features and shortterm outcomes of 144 patients with SARS in the greater Toronto area. JAMA 2003;289:2801-9. https://doi.org/10.1001/jama.289.21.JOC30885

6. Garbati MA, Fagbo SF, Fang VJ, et al. A comparative study of clinical presentation and risk factors for adverse outcome in patients hospitalised with acute respiratory disease due to MERS coronavirus or other causes. PLoS One 2016;11:e0165978. https://doi.org/10.1371/ journal.pone. 0165978

7. Schoen K, Horvat N, Guerreiro NFC, de Castro I, de Giassi KS. Spectrum of clinical and radiographic findings in patients with diagnosis of $\mathrm{H} 1 \mathrm{~N} 1$ and correlation with clinical severity. BMC Infect Dis 2019;19(1):964. https://doi.org/10.1186/s12879-019-4592-0

8. Li B, Yang J, Zhao F, et al. Prevalence and impact of cardiovascular metabolic diseases on COVID-19 in China. Clin Res Cardiol 2020; 109(5):531-8. https://doi.org/10.1007/s00392-020-01626-9

9. Fadini GP, Morieri ML, Longato E, Avogaro A. Prevalence and impact of diabetes among people infected with SARS-CoV-2. J Endocrinol Invest 2020;43(6):867-9. https://doi.org/10.1007/s40618-020-01236-2

Correspondence: Dr Eunice O Wiafe Centre for Diabetes and Endocrinology, Level 1, Junction 3, York Teaching Hospitals NHS Foundation Trust, Wiggington Road, York, YO31 8HE, UK E-mail: Eunice.Wiafe@york.nhs.uk

Br J Diabetes 2021;21:154-155 https://doi.org/10.15277/bjd.2021.280 